\title{
Early use of corticosteroids in non-critical patients with COVID-19 pneumonia (PRED (OVID): a structured summary of a study protocol for a randomised controlled trial
}

Mauricio Salinas ${ }^{1 *} \mathbb{D}$, Paulette Andino ${ }^{2}$, Leonor Palma ${ }^{3}$, Javiera Valencia ${ }^{4}$, Elizabeth Figueroa ${ }^{4}$ and Jhonatan Ortega ${ }^{3}$

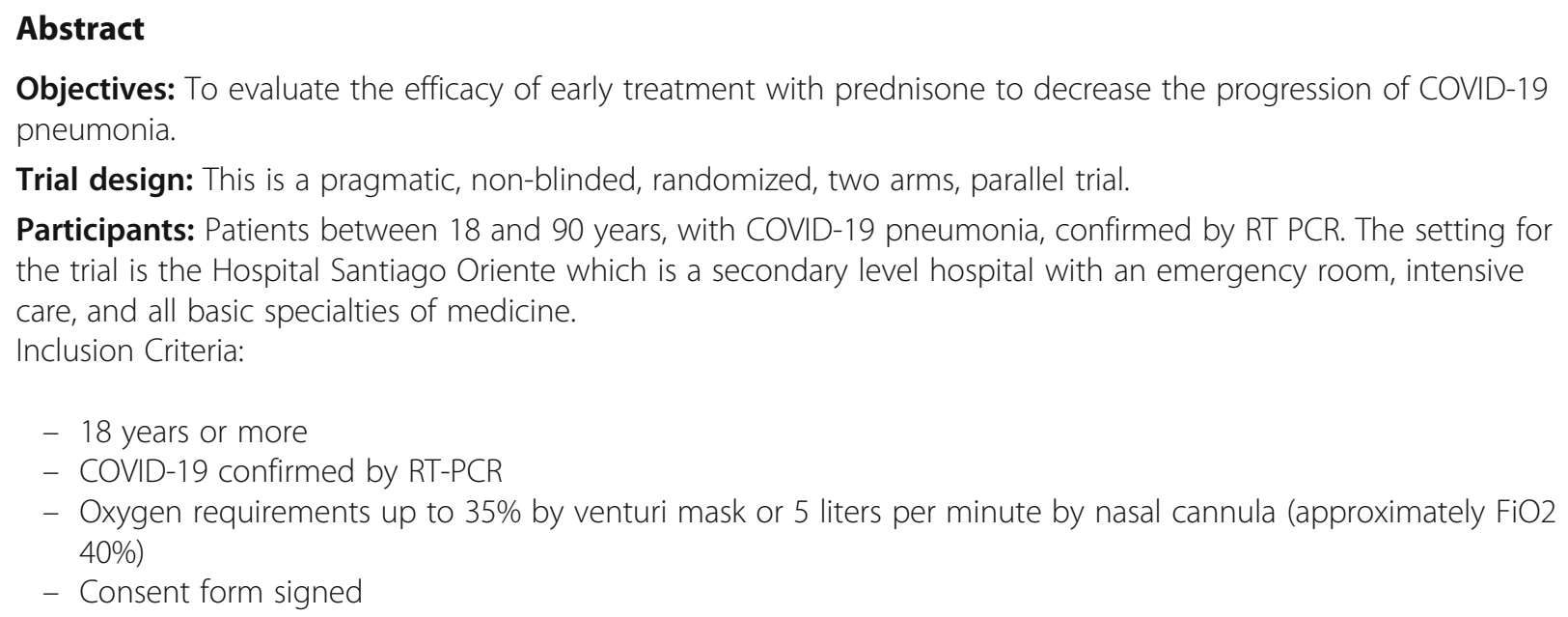

Exclusion Criteria:

- Previous steroid use for more than 48 hours.

- Pregnancy

- Chronic respiratory failure

- Requirements of mechanical ventilation (invasive or no invasive)

- Chronic liver damage Child Pugh B or C

- Chronic kidney disease stage IV or V.

- Immunosuppressed

- Participation in another trial.

(Continued on next page)

\footnotetext{
* Correspondence: Mrsalinas@uchile.cl

${ }^{1}$ Facultad de Medicina, Universidad de Chile, Santiago, Chile

Full list of author information is available at the end of the article
}

C C The Author(s). 2021 Open Access This article is licensed under a Creative Commons Attribution 4.0 International License, which permits use, sharing, adaptation, distribution and reproduction in any medium or format, as long as you give appropriate credit to the original author(s) and the source, provide a link to the Creative Commons licence, and indicate if changes were made. The images or other third party material in this article are included in the article's Creative Commons licence, unless indicated otherwise in a credit line to the material. If material is not included in the article's Creative Commons licence and your intended use is not permitted by statutory regulation or exceeds the permitted use, you will need to obtain permission directly from the copyright holder. To view a copy of this licence, visit http://creativecommons.org/licenses/by/4.0/ The Creative Commons Public Domain Dedication waiver (http://creativecommons.org/publicdomain/zero/1.0/) applies to the data made available in this article, unless otherwise stated in a credit line to the data. 
(Continued from previous page)

Intervention and comparator: Experimental arm

Prednisone $40 \mathrm{mg}$ days 1 to 4. Then Prednisone $20 \mathrm{mg}$ days 5 to 8 . Usual care defined by the attending physician. Control arm

No intervention. Usual care defined by the attending physician.

Main outcomes: Primary outcome

Composite Primary End-point: Admission to ICU, Need for Invasive Mechanical Ventilation or All-cause Death by Day 28

Secondary outcomes (followed until day 28).

- Time to respiratory deterioration

- Incidence of patients requiring mechanical ventilation:

- Number of days on mechanical ventilation

Special emphasis will be placed on observing the following serious adverse events

- Deterioration of the glycemic profile that requires the use of insulin

- Delirium

- Incidence of hospital infections (pneumonia, urinary tract infection, device associated infections)

- Cumulative incidence of grade 3 and 4 adverse events (AE).

- Interruption or temporary suspension of treatment for any reason

Randomisation: Randomisation in permuted block. Computer generated random numbers in an allocation rate of 1:1. Stata 14.0 was used.

Allocated by the principal investigator (direct communication).

Blinding (masking): Patients not blinded.

Caregivers not blinded.

Participants not blinded.

Statistician will not know the allocation.

Numbers to be randomised (sample size): 92 patients in each arm. 184 total number of patients.

Trial Status: Protocol version 2.0., approved October 2, 2020.

Trial ongoing.

Recruitment start: June 23, 2020.

Anticipate finish recruiting: November 30, 2020.

The protocol has been submitted before the last patient and last visit. The delay in sending to publication is responsibility of the authors.

Trial registration: Early Use of Corticosteroids in Non-critical Patients With COVID-19 Pneumonia (PREDCOVID). Registration number NCT04451174. Date of trial registration: June 26, 2020.

Full protocol: The full protocol is attached as an additional file, accessible from the Trials website (Additional file 1). In the interest in expediting dissemination of this material, the familiar formatting has been eliminated; this Letter serves as a summary of the key elements of the full protocol.

Keywords: COVID-19, Randomised controlled trial, protocol, pragmatic clinical trial, prednisone

\section{Supplementary Information}

The online version contains supplementary material available at https://doi. org/10.1186/s13063-021-05046-6.

Additional file 1. Full study protocal.

Acknowledgements

Not applicable
Statement

I certify that this trial has received ethical approval from the referred ethical committee.

Consent to participate is mandatory for all participants in this trial

\section{Authors' contributions}

MS. Conception. Design of work. PA. Conception. Design of work Organization and supervising work team. LP. Organization and supervising work team. Collect all patient's information and check it. JV. Obtain Consent. Follow up of patients. Collect patient information. EF. Obtain Consent. Follow 
up of patients. Collect patient information. JO. Obtain Consent. Follow up of patients. Collect patient information. All of the authors have revised and approved the protocol.

\section{Funding}

The study is not funded.

\section{Availability of data and materials}

Data will be available from the author on reasonable request. Please contact mrsalinas@uchile.cl

\section{Ethics approval and consent to participate}

Approved by the Scientific Ethical Committee of the Servicio de Salud Metropolitano Oriente on June 16, 2020 under the title "Uso precoz de corticoides en pacientes hospitalizados con enfermedad moderada por COVID -19 (PREDCOVID)".

\section{Consent for publication}

Not applicable.

\section{Competing interests}

The authors declare that they have no competing interest

\section{Author details}

${ }^{1}$ Facultad de Medicina, Universidad de Chile, Santiago, Chile. ${ }^{2}$ Instituto Nacional del Tórax, Santiago, Chile. ${ }^{3}$ Hospital Santiago Oriente, Santiago, Chile. ${ }^{4}$ Universidad de Los Andes Facultad de Medicina, Santiago, Chile.

Received: 31 December 2020 Accepted: 16 January 2021

Published online: 26 January 2021

\section{Publisher's Note}

Springer Nature remains neutral with regard to jurisdictional claims in published maps and institutional affiliations. 